\title{
Correction to: Prognostic significance of serum inflammatory markers in esophageal cancer
}

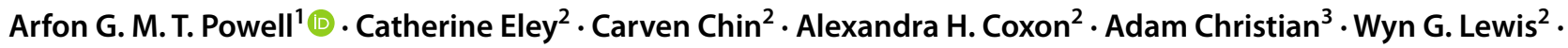 \\ South East Wales Oesophagogastric Cancer Collaborative
}

Published online: 12 April 2021

(C) The Author(s) 2021

\section{Correction to: Esophagus (2021) 18:267-277}

https://doi.org/10.1007/s10388-020-00772-3

In the original publication of the article, under the section "Clinicopathological characteristics", the thresholds used for NLR was published incorrectly as 2.5 . The correct value is 5.5.

The correct sentence should read as follows, "These derivative measurements were dichotomised into low and high groups by 5.5 for NLR, and 150 for PLR [6]".

Open Access This article is licensed under a Creative Commons Attribution 4.0 International License, which permits use, sharing, adaptation, distribution and reproduction in any medium or format, as long as you give appropriate credit to the original author(s) and the source, provide a link to the Creative Commons licence, and indicate if changes were made. The images or other third party material in this article are included in the article's Creative Commons licence, unless indicated otherwise in a credit line to the material. If material is not included in the article's Creative Commons licence and your intended use is not permitted by statutory regulation or exceeds the permitted use, you will need to obtain permission directly from the copyright holder. To view a copy of this licence, visit http://creativecommons.org/licenses/by/4.0/.

Publisher's Note Springer Nature remains neutral with regard to jurisdictional claims in published maps and institutional affiliations.
The original article can be found online at https://doi.org/10.1007/ s10388-020-00772-3

\section{Arfon G. M. T. Powell}

powella16@cardiff.ac.uk

1 Division of Cancer and Genetics, University Hospital of Wales, Cardiff University, Heath Park, Cardiff, UK

2 Department of Surgery, Cardiff \& Vale University Health Board, University Hospital of Wales, Heath Park, Cardiff, UK

3 Department of Pathology, Cardiff \& Vale University Health Board, University Hospital of Wales, Heath Park, Cardiff, UK 